\title{
ANALISIS IMPLEMENTASI KEBIJAKAN AKREDITASI SEKOLAH MENENGAH PERTAMA TAHUN 2005-2009 DI PROVINSI DKI JAKARTA
}

\author{
Agus Sulistyanto*
}

\begin{abstract}
The purpose of this research is to analyze the implementation of accreditation policy of Junior High School period 2005-2009. This research was conducted in the implementation of policies in DKI Jakarta Province with Descriptive and explanations of secondary and primary data methods. The result of research are as follows: (1). The government of DKI Jakarta Province has implemented the accreditation policies are carried out accreditation agency (2). Accreditation agency performance is not optimal due to the change of regulation policy implementation accreditation. (3). There is Junior High School in DKI Jakarta is not feasible in providing educational services, (4). The grade of acreditation inclines to describe the result of quality education, meanwhile the grade of acreditation of international school (RSBI) always describe the result of quality education. It implies that the implementation of accreditation in DKI Jakarta Province, al though there are still schools that have not been feasible, but most school accreditation results tend to have a description the actual quality of education.
\end{abstract}

Keywords : Policy, accreditation, quality of education.

\section{PENDAHULUAN}

Dalam rangka menyiapkan sumber daya manusia yang bermutu yang sangat diperlukan untuk mengantisipasi berbagai perubahan di era globalisasi dan pasar bebas maka bangsa Indonesia mengutamakan pembangunan pendidikan. Pembangunan pendidikan bangsa secara tegas tercantum pada pembukaan Undang-Undang Dasar Republik Indonesia 1945, yaitu untuk melindungi segenap bangsa Indonesia dan seluruh tumpah darah Indonesia, dan untuk memajukan kesejahteraan umum, mencerdaskan kehidupan bangsa, dan ikut melaksanakan ketertiban dunia yang berdasarkan kemerdekaan, perdamaian abadi dan keadilan sosial. Pembangunan pendidikan bangsa ini merupakan tujuan negara kesatuan Republik Indonesia kemudian dituangkan dalam batang tubuh Undang-Undang Dasar 1945, yaitu pasal 31, "setiap warga negara berhak mendapat pendidikan."

Undang-Undang Republik Indonesia Nomor 20 Tahun 2003 tentang Sistem Pendidikan Nasional (UU 20/2003). Pasal 5 menyebutkan bahwa setiap warga Negara mempunyai hak yang sama untuk memperoleh pendidikan yang bermutu. SMP merupakan satuan pendidikan di tingkat dasar harus memberikan pelayanan pendidikan yang bermutu sesuai dengan bakat, minat dan kemampuannya yang ditempuh dalam waktu 3 tahun sesuai amanat UU 20/2003. Kaitannya dengan pelayanan pendidikan yang bermutu di tingkat satuan pendidikan SMP, dalam Pasal 60 ayat 1 (UU 20/2003) menyebutkan Akreditasi Sekolah dilaksanakan untuk menentukan kelayakan suatu satuan pendidikan. Peraturan Pemerintah (PP) No. 19 Tahun 2005 tentang Standar Nasional Pendidikan (SNP) menyatakan sasaran penilaian akreditasi adalah kelayakan suatu sekolah untuk mampu memberikan layanan pendidikan yang bermutu. Ditegaskan lagi dalam Keputusan Menteri Pendidikan Nasional (Kepmendiknas) No. 087/U/2002 tentang Akreditasi Sekolah dan Peraturan Menteri

\footnotetext{
* Pengawas SMP Sudin Dikdas Jakarta Utara
} 
Pendidikan Nasional (Permendiknas) No. 29 Tahun 2005 tentang Badan Akreditasi Nasional Sekolah dan Madrasah (BAN-S/M) dalam menetapkan komponen-komponen sebagai indikator kelayakan suatu sekolah untuk mampu memberikan layanan pendidikan yang bermutu. Namun sampai saat ini, setelah lebih dari 4 tahun sejak diberlakukan secara nasional Undang-Undang No. 20 Tahun 2003 tentang Sisdiknas dan Kepmendiknas No. 087/U/2002, keadaan SMP di DKI Jakarta ternyata masih banyak yang belum layak dan belum dapat memberikan layanan pendidikan yang bermutu untuk peserta didiknya. Sekolah yang belum layak menurut penilaian badan akreditasi dan aturan lain mendapat sanksi tidak boleh menyelenggarakan ujian mandiri artinya masih bergabung dengan sekolah yang terakreditasi.

Sebagai ibukota negara, Jakarta merupakan barometer dalam memberikan pelayanan pendidikan di Indonesia dengan Anggaran Pendapatan Belanja Daerah (APBD) sudah melampui 20\% dan telah membebaskan biaya pendidikan bagi siswa SD dan SMP sejak tahun 2006 hingga kini. Dinas Pendidikan Provinsi DKI Jakarta mempunyai program sekolah yang berada di provinsinya mempunyai pagu atau patok banding (benchmarking) tidak saja dengan sekolah yang ada di dalam negeri tetapi juga dengan di ibukota negara tetangga misalnya, Singapura dan Kuala Lumpur. Dengan kondisi yang telah dijelaskan sebelumnya, maka sangat diperlukan analisis yang menyeluruh terhadap kebijakan-kebijakan nasional tentang akreditasi SMP. Kebutuhan terhadap analisis kebijakan ini nyata-nyata diperlukan bagi Pemerintah Daerah Provinsi DKI Jakarta dan Kepala Sekolah untuk peningkatan mutu pendidikan. Fungsi pengawasan dan pembinaan yang merupakan tugas Dinas Pendidikan Provinsi DKI Jakarta agar dicapai kinerja SMP secara optimal. Sejauh ini analisis menyeluruh yang meliputi implementasi, hasil dan rekomendasi hasil akreditasi belum dilaksanakan.

\section{Kebijakan Publik}

Kebijakan publik dinyatakan oleh Thomas Dye dalam Birkland (2001:8), "whatever goverments choose to do or not to do." Kebijakan publik adalah apapun yang pemerintah pilih untuk melakukan atau tidak melakukan sesuatu. Pendapat senada dikemukakan oleh Quade (1979:3), "a public policy decision made by society for itself (The election of a president, for instance) or for society by its elected representatives-decisions taken by individuals or groups that have material effects on individuals other than those involved in making the decisions". Keputusan kebijakan publik adalah keputusan yang dibuat masyarakat (contohnya pemilihan Presiden) atau untuk masyarakat oleh wakil terpilih, keputusan diambil oleh perorangan atau kelompok yang mempunyai efek materi pada individu lain selain yang terlibat dalam pembuatan keputusan.

\section{Penelitian Kebijakan (Policy Research)}

Majchrzak (1984:12) mendefinisikan, "the proses of conducting research on, or analysis of, a fundamental sicial problem in order to provide policymakers with pragmatic, action-oriented recommendations for alleviating the problem." Definisi tersebut menunjukkan bahwa penelitian

kebijakan adalah proses penyelenggaraan penelitian untuk mendukung kebijakan atau analisis terhadap masalah-masalah sosial yang bersifat fundamental, dilakukan secara teratur

untuk membantu pengambil kebijakan memecahkan masalah dengan jalan menyediakan rekomendasi yang berorientasi pada tindakan atau tingkah laku pragmatik.

Mengutip Haas dan Springer (1998:4), "policy research is a catch all term embracing the many information gathering and processing activities that public agencies engage in to 
facilitate decision making". Semua istilah mencakup banyak kegiatan pengumpulan dan pemprosesan informasi yang melibatkan lembaga publik untuk memfasilitasi pembuatan keputusan. Senada dengan di atas Brill (1978:1) mendefinisikan, "policy research is concerned with mapping alternative approaches and with specifying potential differences in the intention, effect, and cost of various program." Penelitian kebijakan terfokus pada pemetaan dengan pendekatan alternatif dan dengan merinci perbedaan kemampuan pada tujuan, efek dan biaya dari berbagai program.

\section{Akreditasi}

Davies (1996:586) mengatakan, "accreditation is a process of certifying the competence of a person in an area of capability." Akreditasi adalah proses pensertifikasi dari kompetensi seseorang pada lingkup kemampuannya. Ditambahkan definisi akreditasi oleh BSI Worldwide Business Standards Magazine (2011:1) menyebutkan, "accreditation is when an organization that provides certification testing and inspection services is is assessed by a third party against internationally recognized standards. It demonstrates the organization is competence, impartiality and performance capability and is the key to reducing risk and ensuring that consumers, supplier and purchasers can have confedence in the service provided." Dalam pengertian ini lembaga tersebut disertifikasi, dinilai dan diperiksa dengan standar internasional tentang kompetensi, kenetralan dan kinerjanya sebagai bentuk penjaminan layanan pada pelanggan.

Definisi-definisi di atas menegaskan pada kegiatan akreditasi yang dilaksanakan oleh badan akreditasi terkait dengan mutu pendidikan mengacu standar tertentu yaitu untuk penjaminan mutu dan peningkatan mutu. Hal tersebut diperjelas lagi dengan pernyataan Harman dan Meek dalam Patil dan Gray (2009:4), “....systematic management and assessment proce-dures adopted by a higher education institution or system to monitor performance and to ensure achievement of quality outputs or improved quality." Manajemen yang sistematik dan prosedur penilaian yang diadopsi oleh lembaga pendidikan tinggi atau suatu sistem untuk memonitor kinerja dan penjaminan atau peningkatan mutu hasil prestasi. Dari uraian di atas dapat disintesiskan akreditasi adalah proses evaluasi suatu lembaga dengan membandingkan atau merujukkan sesuatu hal dari segi kondisi, keadaan atau yang lainnya dengan yang sudah standar untuk mendapatkan pengakuan secara resmi dalam rangka penjaminan mutu.

\section{Mutu Pendidikan}

Sallis (2002:15) mendefinisikan, "quality can be defined as that which satisfies and exceeds customers' needs and wants". Orientasi mutu sebagian besar di atas adalah pada kepuasan pemakai atau pelanggan, lebih lanjut ide tentang mutu ini berkembang seiring dengan perkembang ilmu dan teknologi dalam meningkatkan pelayanan dan kepuasan pelanggan yaitu kontrol mutu (quality control), jaminan mutu (quality assurance) dan mutu terpadu

(total quality). Besterfield (1994:451) menyebut, "quality was defined as meeting or exceeding the customer's expectation." Mutu adalah terlampauinya kepuasan pelanggan. Berdasarkan

uraian-uraian tentang mutu di atas maka dapat diambil kesimpulan mutu adalah suatu keadaan yang diperlukan seluruh masyarakat pelanggan mengacu pada standar yang ditetapkan.

Gerakan peningkatan mutu di bidang pendidikan masih tergolong baru dan mengadopsi dari dunia industri. Mulai dari beberapa Universitas di Amerika awal 1980-an 
dengan menerapkan konsep Total Quality Management (TQM), disusul Inggris awal 1990-an dan berkembang di seluruh dunia. Kemudian gagasan-gagasan tentang mutu dikembangkan secara terus menerus oleh perguruan tinggi dan diteliti dan diimplementasikan di sekolah-sekolah. Peningkatan mutu semakin penting bagi institusi yang digunakan untuk memperoleh kontrol yang lebih baik melalui usahanya sendiri. Patil dan Gray (2009:5) menyoroti betapa pentingnya mutu pendidikan, dikatakannya, "quality in the sense of achieving academic excelence has always been a central value in higher education." Mutu adalah yang memiliki maksud sebagai prestasi akademik yang unggul yang selalu merupakan titik pusat dalam dunia pendidikan.

Owen (1992:4) menyatakan, "the control of quality which lies behind assurances about level is in the hands of governors, heads and other teachers. Governor know that their own position may still be largely nominal. Teachers have the power to provide quality but they - and heads too - choose to look upon the management of quality mainly as a matter of personal effort and and personal trust." Pengendalian jaminan mutu adalah tugas pemerintah, kepala sekolah dan para guru. Pemerintah tahu bahwa kedudukannya masih besar dalam masalah tersebut. Guru mempunyai kekuatan untuk menetapkan mutu, tapi bersama kepala sekolah, mereka menentukan manajemen mutu sebagai karya pribadi dan kepercayaan pribadi guru atau kepala sekolah. Dengan penjelasan tersebut di atas peningkatan mutu pendidikan yang dimaksud pada penelitian ini adalah mutu akademik yaitu hasil nilai Ujian Nasional di tiap SMP di DKI Jakarta.

Dengan demikian karena standar berbeda-beda antara satu pelanggan dengan pelanggan lainnya maka mutu bersifat relatif. Dari uraian di atas dapat disintesiskan mutu adalah suatu keadaan yang diperlukan seluruh masyarakat pelanggan mengacu pada standar yang ditetapkan. Dengan demikian karena standar berbeda-beda antara satu pelanggan dengan pelanggan lainnya maka mutu bersifat relatif.

\section{METODE}

Penelitian ini menggunakan pendekatan studi dokumen (documentary study) dan wawancara untuk menganalisis implementasi kebijakan akreditasi dan hasil implementasi kebijakan akreditasi SMP dalam rangka peningkatan mutu pendidikan di Provinsi DKI Jakarta. Bahan analisis yang digunakan dalam penelitian ini adalah data sekunder (secondary data) yaitu berupa dokumen-dokumen. Analisis kebijakan difokuskan pada implementasi dan hasil implementasinya. Pertama analisis implementasi kebijakan akreditasi SMP. Kedua analisis hasil implementasi kebijakan akreditasi SMP dalam rangka peningkatan mutu pendidikan. Ketiga, analisis hasil implementasi kebijakan akreditasi SMP dalam rangka

peningkatan mutu pendidikan di SMP SSN dan RSBI di Provinsi DKI Jakarta. Proses analisis kebijakan dalam penelitian ini menggunakan pendekatan model Matland.

\section{HASIL DAN PEMBAHASAN}

Implementasi kebijakan akreditasi SMP di Provinsi DKI Jakarta diawali dengan pembentukan lembaga akreditasi yang disebut Badan Akreditasi Sekolah (BAS) Provinsi yang merupakan lembaga akreditasi di bawah Badan Akreditasi Nasional Sekolah (BASNAS). BAS Provinsi DKI Jakarta terdiri dari BAS Dikdas dan BAS Dikmen, BAS Dikdas 
tersebut yang mengakreditasi SMP berdasarkan Keputusan Gubernur yang merupakan amanah Kepmendiknas. BAS Dikdas bertugas dari tahun 2003 sampai tahun 2006. Kemudian pada tahun 2007 BAS Dikdas dan Dikmen berubah menjadi Badan Akreditasi Provinsi Sekolah/ Madrasah (BAP-S/M) yang merupakan lembaga akreditasi di bawah Badan Akreditasi Nasional Sekolah/Madrasah (BAN-S/M). BAP-S/M dibentuk mengacu pada Peraturan Gubernur berdasarkan amanah Peraturan Pemerintah. BAP-S/M mempunyai wewenang yang lebih besar dibandingkan BAS Provinsi. BAP-S/M mengakreditasi tidak hanya sekolah di bawah Kemendiknas namun juga sekolah/madarasah di bawah Kementerian Agama (Kemendag).

Pada penelitian lapangan ditemukan bahwa model kelembagaan akreditasi menggunakan pendekatan Model Matland yaitu implementasi secara administratif, kebijakan ini mempunyai ambiguitas yang rendah dan konflik yang rendah dan dimodifikasi menjadi implementasi secara dipaksakan atau politik. Badan akreditasi setelah menilai akreditasi maka hasil penilaiannya direkomendasikan kepada Pemerintah atau Pemerintah Daerah dalam hal ini Dinas Pendidikan Provinsi DKI Jakarta untuk ditindaklanjuti dalam rangka peningkatan mutu pendidikan. Tindak lanjutnya sesuai peraturan yang berlaku, dalam hal pelaksanakan ujian maka sekolah yang tidak layak tidak diperkenankan melaksanakan ujian mandiri. Kelayakan sekolah diantaranya ditentukan dari status akreditasi sekolah dan jumlah peserta ujian. Sekolah dapat menyelenggarakan ujian mandiri adalah sekolah tersebut sudah terakreditasi dan peserta didik yang mengikuti ujian minimal 20 orang. Apabila tidak maka sekolah akan bergabung dengan sekolah terakreditasi yang ditunjuk oleh Dinas Pendidikan. Selain penggabungan dalam melaksanakan ujian, apabila dalam penilaian pengawas tidak ada peningkatan mutu maka diusulkan untuk dicabut ijin operasional sekolah tetapi dengan tidak mengorbankan sumber daya pendidikan terkait peserta didik, tenaga pendidik dan kependidikan.

Temuan empiris hasil penelitian telah diakreditasi sebanyak 919 sekolah SMP di Provinsi DKI Jakarta pada periode 2005-2009 dan hasil akreditasi tersebut cenderung mengalami peningkatan dalam memperoleh peringkat Amat Baik (A). Namun hal ini Jakarta sebagai ibukota negara belum dapat menggambarkan sebagai barometer pendidikan di Indonesia, karena terdapat sekolah yang tidak terakreditasi dan terakreditasi C. Dari hasil akreditasi selama periode 2005-2009 yang dilaksanakan 2 lembaga akreditasi yaitu BAS Dikdas dan BAP-S/M DKI Jakarta. Menunjukkan bahwa Kinerja lembaga akreditasi tersebut tidak optimal dari 1023 sekolah terakreditasi sebanyak 919 sekolah.

Perkembangan sekolah terakreditasi setiap tahunnya dan secara kumulatif dari periode tahun 2005 sampai tahun 2009 terhadap kategori dengan indikator rerata UN sebagian besar pada posisi sesuai peringkat akreditasinya, sekolah terakreditasi A dengan perolehan rerata UN di kategori A, terakreditasi B dengan perolehan B dan terakreditasi C perolehan rerata UN pada karegori $C$ walaupun kualitas rerata UN di level itu fluktuatif naik turun setiap tahunnya. Pergerakan sekolah terakreditasi dari tahun 2005 sampai 2009 cenderung mengalami kenaikan rerata UN dari C ke B.

Menurut perhitungan kumulatif sekolah terakreditasi dari periode tahun 2006 sampai 2009 mengalami kecenderungan meningkat untuk level A peningkatan tersebut diperoleh dari sekolah yang teakreditasi A, namun sekolah terakreditasi A mengalami naik turun pada perolehan rerata UN di level A setiap tahunnya. Demikian pula untuk kategori sekolah dengan indikator rerata ujian nasional di level B terjadi peningkatan. Sedangkan sekolah yang mendapat pencapaian rerata UN di level C menurun karena sekolah yang terakreditasi C mengalami kenaikan perolehan kategori pencapaian UN menjadi B atau 
bahkan A. Sekolah dengan akreditasi A sebagian besar memperoleh nilai rerata UN di kategori A demikian pula yang terakreditasi B sebagian besar memperoleh nilai B. Sama halnya dengan sekolah yang terakreditasi $C$ sebagian besar memperoleh nilai $C$ rerata $U N$ periode tahun 2005-2009.

Perkembangan SMPSSN dan RSBI terakreditasi dan kategori dengan indikator rerata UN dari dalam 2005-2009 di Provinsi DKI Jakarta cenderung di posisi A, namun kualitasnya naik turun setiap tahunnya. Pada SMP SSN terakreditasi dengan kategori indikator rerata UN pada tahun 2005-2009 mengalami naik turun kualitas namun sebagian besar di posisi A. Sedangkan untuk SMP RSBI pada kategori dengan indikator rerata UN konsisten pada level A dan hampir seluruhnya memperoleh sertifi-kasi ISO $9000: 2000$.

\section{Telaah Kritis atas Hasil Kebijakan Implementasi Akreditasi Sekolah Menengah Pertama di Provinsi DKI Jakarta.}

Penelitian ini pada dasarnya memfokuskan pada analisis implementasi kebijakan akreditasi dan analisis hasil implementasi kebijakan dalam rangka peningkatan mutu pendidikan Sekolah Menengah Pertama di Provinsi DKI Jakarta. Implementasi kebijakan akreditasi dari tahun 2005-2006 dilaksanakan oleh Badan Akreditasi Sekolah (BAS) Dikdas, sedangkan oleh Badan Akreditasi Provinsi-Sekolah/Madrasah (BAP-S/M) DKI Jakarta dari tahun 2007-2009. Untuk lebih jelasnya disajikan perkembangan peringkat akreditasi dengan sekolah hasil akreditasi periode BAS Dikdas dan BAP-S/M DKI Jakarta.

Tabel 1 Perkembangan SMPterakreditasi periode BAS Dikdas dan BAP-S/M di DKI Jakarta.

\begin{tabular}{|c|c|c|c|c|c|c|c|}
\hline \multirow{3}{*}{ Periode } & \multirow{3}{*}{$\begin{array}{c}\text { Tahun } \\
\text { Akreditasi }\end{array}$} & \multicolumn{6}{|c|}{ Akreditasi } \\
\hline & & \multicolumn{2}{|l|}{ A } & \multicolumn{2}{|l|}{ B } & \multicolumn{2}{|l|}{ C } \\
\hline & & JML SMP & $\%$ & JML SMP & $\%$ & JML SMP & $\%$ \\
\hline \multirow{2}{*}{$\begin{array}{c}\text { Periode BAS } \\
\text { Dikdas }\end{array}$} & 2005 & 61 & 38.85 & 79 & 50.32 & 17 & 10.83 \\
\hline & $2005-2006$ & 138 & 38.87 & 184 & 51.83 & 33 & 9.30 \\
\hline \multirow{3}{*}{$\begin{array}{c}\text { Periode BAP- } \\
\text { S/M }\end{array}$} & 2007 & 129 & 53.97 & 98 & 41.00 & 12 & 5.02 \\
\hline & $2007-2008$ & 191 & 54.89 & 143 & 41.09 & 14 & 4.02 \\
\hline & \begin{tabular}{|l|}
$2007-2009$ \\
\end{tabular} & 329 & 58.33 & 216 & 38.30 & 19 & 3.37 \\
\hline
\end{tabular}

Implementasi kebijakan dalam rangka peningkatan mutu pendidikan SMP di Provinsi DKI Jakarta tampak pada tabel 1 bahwa hingga tahun 2009 sekolah yg telah di akreditasi A sebanyak 467 sekolah, akreditasi B sebanyak 400 sekolah dan akreditasi C sebanyak 52 sekolah. Namun, hasil pencapaian tersebut harus ditelaah secara kritis karena beberapa alasan. Alasan Pertama, hasil akreditasi dengan nilai A semakin meningkat setiap tahunnya. Dengan demikian dapat dikemukaan mutu hasil akreditasi makin baik dapat dilihat dari penilaian dari periode BAS Dikdas 38,87\%, periode BAPS/M 58,33\% maka ada peningkatan hasil akreditasi A sebesar 19,46\%.

Alasan kedua, ketika sekolah memperoleh peringkat akreditasi sangat memuaskan atau nilai $\mathrm{A}$, namun kenyataannya tidak menggambarkan mutu akademik sekolah yaitu mencapai nilai akademis UN di level C, D dan E. Demikian pula sekolah dengan peringkat akreditasi B memperoleh nilai Ujian Nasional di kategori D atau E. Sedangkan sekolah dengan akreditasi A minimal memiliki mutu akademik UN di level B seperti yang dipersyaratkan untuk sekolah standar nasional nilai UN rata-rata lebih dari 6,35 di tahun 2006/2007 dan peringkat akreditasi minimal B. Masih memiliki batas-batas yang dipersyaratkan. Sementara itu, penilaian akreditasi mencakup 9 komponen periode BAS Dikdas. Komponen Kurikulum dan Pembelajaran, Admnistrasi dan Manajemen, Organisasi 
dan Kelembagaan, Sarana dan Prasarana, Ketenagaan, Pembiayaan dan Pendanaan, Peserta Didik, Peran Serta Masyarakat, dan Lingkungan dan Budaya. Periode BAP-S/M mencakup 8 SNP. Standar Isi, Standar Proses, Standar Kompetensi Lulusan, Standar Pendidikan dan Tenaga Kependidikan, Standar Sarana dan Prasarana, Standar Pengelolaan, Standar Pembiayaan dan Standar Penilaian Pendidikan. Faktanya juga terdapat sekolah terakreditasi B memperoleh rerata UN di level A dan sekolah terakreditasi C memperoleh rerata UN di level B dengan persentase yang cukup signifikan. Untuk lebih jelasnya berikut ini perkembangan sekolah terakreditasi berdasarkan kategori indikator rerata UN periode pelaksanaan BAS Dikdas dan BAP-S/M DKI Jakarta.

Tabel 2. Perkembangan SMP terakreditasi dengan indikator rerata UN periode BAS Dikdas dan BAP-S/M DKI Jakarta

\begin{tabular}{|c|c|c|c|c|c|c|c|}
\hline \multirow{2}{*}{ Periode } & \multirow{2}{*}{$\begin{array}{c}\text { Hasil } \\
\text { akreditasi }\end{array}$} & \multicolumn{4}{|c|}{ Perolehan Prestasi UN } & \multirow{2}{*}{ Jumlah } & \multirow{2}{*}{$\%$} \\
\hline & & $\mathbf{A}$ & B & $\mathbf{C}$ & D & & \\
\hline Tahun 2005 & $A$ & 32 & 12 & 13 & 4 & 61 & 39 \\
\hline Periode BAS & $\mathrm{B}$ & 5 & 27 & 36 & 11 & 79 & 50 \\
\hline Prov. DKI Jakarta & $\mathrm{C}$ & 0 & 3 & 9 & 5 & 17 & 11 \\
\hline \multicolumn{2}{|c|}{ Jumlah } & 37 & 42 & 58 & 20 & 157 & 100 \\
\hline Tahun 2005 - 2006 & A & 74 & 40 & 20 & 4 & 138 & 39 \\
\hline Periode BAS & $\mathrm{B}$ & 19 & 84 & 69 & 12 & 184 & 52 \\
\hline Prov. DKI Jakarta & $\mathrm{C}$ & 1 & 10 & 16 & 6 & 33 & 9 \\
\hline \multicolumn{2}{|c|}{ Jumlah } & 94 & 134 & 105 & 22 & 355 & 100 \\
\hline Tahun 2007 & A & 74 & 40 & 20 & 4 & 138 & 56 \\
\hline Periode BAP & $\mathrm{B}$ & 8 & 47 & 43 & 0 & 98 & 40 \\
\hline Prov. DKI Jakarta & $\mathrm{C}$ & 1 & 4 & 7 & 0 & 12 & 5 \\
\hline \multicolumn{2}{|c|}{ Jumlah } & 83 & 91 & 70 & 4 & 248 & 100 \\
\hline Tahun 2007 - 2008 & A & 83 & 89 & 19 & 0 & 191 & 55 \\
\hline Periode BAP & $\mathrm{B}$ & 17 & 83 & 43 & 0 & 143 & 41 \\
\hline Prov. DKI Jakarta & $\mathrm{C}$ & 1 & 6 & 7 & 0 & 14 & 4 \\
\hline \multicolumn{2}{|c|}{ Jumlah } & 101 & 178 & 69 & 0 & 348 & 100 \\
\hline Tahun 2007 - 2009 & $A$ & 138 & 147 & 44 & 0 & 329 & 58 \\
\hline Periode BAP & $\mathrm{B}$ & 24 & 126 & 66 & 0 & 216 & 38 \\
\hline Prov. DKI Jakarta & $\mathrm{C}$ & 1 & 9 & 9 & 0 & 19 & 3 \\
\hline \multicolumn{2}{|c|}{ Jumlah } & 163 & 282 & 119 & 0 & 564 & 100 \\
\hline
\end{tabular}

Dapat dilihat pada tabel 2 sekolah dengan peringkat akreditasi A dengan nilai mutu akademik Ujian Nasional A terjadi peningkatan dari periode BAS Dikdas ke periode BAPS/M sebanyak 2,42\%. Ketika peringkat akreditasi A tidak dapat memperoleh prestasi akademik di level A atau B, namun memperoleh prestasi akademik di level C bahkan pada periode BAS Dikdas yaitu antara tahun 2005 sampai dengan 2006 sekolah dengan peringkat akreditasi A memperoleh nilai UN di level C dan D. Lain halnya dengan sekolah peringkat Akreditasi B dan C pada periode BAS terjadi peningkatan hasil akademik Ujian Nasional, begitu juga pada periode BAP-S/M Jakarta.

Alasan ketiga, pemasok hasil UN setiap tahunnya dari yang tertinggi dan terendah sebagian besar adalah SMP swasta. Disebabkan diantaranya jumlah sekolah swasta lebih banyak, di DKI Jakarta lebih dari 72\% SMP terdiri dari sekolah swasta. Sedangkan sekolah negeri posisinya di tengah-tengah. Ranking tertinggi setiap tahunnya perolehan nilai UN tertinggi sekolah swasta sebaliknya rangking terendah juga didominasi oleh sekolah swasta.

Alasan keempat, menurunnya nilai ujian nasional disebabkan karena :

1. Semakin ketatnya pengawasan pada pelaksanaan ujian nasional.

2. Bobot soal UN semakin berbeda pada setiap tahunnya.

3. Dampak psikologis yang muncul pada siswa karena adanya peningkatan standarisasi kelulusan nilai UN.

4. Kualitas siswa di setiap angkatan berbeda. 


\section{PENUTUP}

Kesimpulan. Berdasarkan hasil analisis data, maka dapat disampaikan kesimpulan sebagai berikut:

1) Implementasi kebijakan akreditasi SMP di Provinsi DKI Jakarta berawal dari Pemerintah membentuk lembaga akreditasi Badan Akreditasi Sekolah Nasional (BASNAS) di tingkat pusat melalui Keputusan Menteri Pendidikan Nasional dan di tingkat provinsi dibentuk Badan Akreditasi Sekolah Provinsi (BASPROV) DKI Jakarta yang terdiri dari Badan Akreditasi Sekolah Pendidikan Dasar (BAS Dikdas) dan Badan Akreditasi Sekolah Pendidikan Menengah (BAS Dikmen) melalui Peraturan Gubernur Provinsi DKI Jakarta tahun 2003. Karena terjadi perubahan dan pergantian kebijakan akreditasi, maka pada tahun 2007 BASNAS diganti Badan Akreditasi Nasional Sekolah Madrasah (BAN-S/M) dan BAS Dikdas dan BAS Dikmen DKI Jakarta menjadi Badan Akreditasi Provinsi Sekolah Madrasah (BAP-S/M).

2) Kinerja BAS Dikdas/BAP-S/M DKI Jakarta selama periode tahun 2005-2009 telah mengakreditasi 919 Sekolah Menengah Pertama dari 1023 Sekolah Menengah Pertama yang ada di provinsi DKI Jakarta, sebesar 89,83\% nya. Seharusnya setiap 4 atau 5 tahun Sekolah Menengah Pertama diakreditasi ulang artinya masih ada 6.16\% Sekolah Menengah Pertama yang belum diakreditasi ulang. Kinerja Badan Akreditasi belum optimal dikarenakan adanya pergantian regulasi kebijakan implementasi akreditasi dari Keputusan Menteri Pendidikan Nasional 087/U/2002 ke Peraturan Menteri Pendidikan Nasional 29 tahun 2005, terjadi perubahan kelembagaan dari BAS Dikdas ke BAP-S/M DKI Jakarta. Perkembangan sekolah terakreditasi hasil penilaian periode tahun 2005-2009

cenderung mengalami peningkatan ke peringkat A. Namun sebaliknya di DKI Jakarta sebagai ibukota negara kenyataannya masih terdapat sekolah yang tidak layak dalam pelayanan pendidikan rata-rata sebesar 8,562\% dari tahun 2005-2009.

3) Perkembangan sekolah terakreditasi A terhadap mutu akademik berdasarkan kategori indikator rerata UN pada periode tahun 2005-2009 di Provinsi DKI Jakarta pada kisaran kategori A dan B, sedangkan sekolah terakreditasi B konsisten di kategori B. Berbeda dengan sekolah terakreditasi $C$ memperoleh nilai rerata UN kategori B. Perkembangan sekolah terakreditasi terhadap mutu akademik berdasarkan kategori indikator rerata UN di DKI Jakarta terjadi peningkatan yaitu sejak tahun 2007 sampai 2009 tidak terdapat Sekolah Menengah Pertama di DKI Jakarta yang memperoleh nilai rerata UN di kategori $\mathrm{D}$ dan $\mathrm{E}$.

4) Perkembangan SMPSSN periode tahun 2005-2009 di Provinsi DKI Jakarta terakreditasi A terhadap mutu akademik berdasarkan kategori indikator rerata UN cenderung memperoleh kategori A, walaupun fluktuatif. Sedangkan SMP RSBI senantiasa memperoleh prestasi di kategori A dalam memperoleh rerata UN dan tersertiflkasi ISO 900:2000.

Keterangan Range Nilai UN

Baik Sekali (A) : UN antara $\geq 22,5$ atau nilai rata-rata $>7,5$

Baik (B) : UN antara 22,49-19,5 atau nilai rata-rata 7,49 - 6,5

Cukup (C) : UN antara 19,49-16,5 atau nilai rata-rata 6,49-5,5

Kurang (D) : UN antara 16,49 - 13,5 atau nilai rata-rata 5,49-4,5

Kurang Sekali (E): UN antara $\leq 13,49$ atau nilai rata-rata $<4.49$ 
Rekomendasi. Berdasarkan pembahasan dan temuan yang telah dikemukakan, rekomendasi sebagai implikasi dapat dikemukakan dalam penelitian ini adalah:

1) Rekomendasi bagi Peneliti

Pada penelitian ini, di samping menganalisis tentang implementasi kebijakan akreditasi SMP juga melakukan analisis terhadap hasil-hasil implementasi kebijakan akreditasi dalam rangka peningkatan mutu pendidikan di Provinsi DKI Jakarta dan peningkatan mutu pendidikan di SMP SSN dan RSBI. Hanya saja, analisis ini masih terbatas pada tingkatan SMP wilayah Provinsi DKI Jakarta.

2) Rekomendasi bagi Pelaksana Kebijakan

Dengan akreditasi yang dilaksanakan BAS Dikdas dan BAP-S/M dapat memberikan gambaran pada masyarakat yang sebenarnya mengenai kelayakan sekolah dan gambaran mengenai mutu sekolah. Kenyataan masih ada sekolah yang mendapatkan Akreditasi Amat Baik tetapi belum sesuai dengan gambaran layanan mutu pendidikan yang diharapkan masyarakat. Oleh karena itu perlu kiranya BAP-S/M dapat mempertimbangakan mengikuti prosedur operasi dalam melaksanakan akreditasi distandarkan dengan prosedur operasional penilaian sertifikasi ISO 9000:2000 atau yang sejenisnya. Dinas Pendidikan DKI Jakarta agar melakukan monitoring pada sekolah yang memiliki akreditasi Amat Baik atau Baik namun tidak menggambarkan mutu pendidikan yang sebenarnya untuk merekomendasikan kepada BAP-S/M agar diakreditasi ulang

atau pencabutan terhadap status akreditasi yang telah dimilikinya. 


\section{DAFTAR RUJUKAN}

Besterfield, Dale H. Quality Control. New Jersey: Prentice Hall, 1994.

Bryson, John M. Strategic Planning For Public and Non Profit Organizations. Third edition. San Francisco. Jossey-Bass: 2004.

Dye, Thomas R. Understanding Public Policy. New Jersey: Prentice-Hall Inc, 1981.

Feigenbaum, Armand V. Total Quality Control. New York: McGraw-Hill, Inc, 1991.

Haas, Peter J. and Springer, J. Fred. Applied Policy Research: Concepts and Cases. New York: Garland Publishing, Inc., 1998.

James Hill, Michel dan Peter L. Hupe. Implementing Public Policy: Governance in Theory and Practice. London: SAGE Publi-cations Ltd, 2002.

Lester, James P, dan Joseph Stewart. Public Policy: an Evolutinary Approach. Australia: Wadsworth, 2000.

Majchrzak, Ann. Methods for Policy Reseacrh: Apllied Social Research Methods Series Volume 3. New Delhi: SAGE Publications, Inc. 1984.

Nugroho, Riant. Public Policy. Jakarta: Elex Media Komputindo, 2008.

Owen, Joslyn. Managing Education. New York: Longman, 1992.

Quade, E,S. Analysis for Public Decisions. New York: Elsevier. 1997.

Sallis, Edward. TQM in Education. London: Kogan Page Ltd, 2002.

Sapru, R.K. Public Policy: Art and Craft of Policy Analysis. New Delhi: PHI Learning Private Limited, 2010.

Waluyo. Manajemen Publik; Konsep, Aplikasi dan Implementasinya dalam Pelaksanaan Otonomi Daerah. Bandung: Mandar Maju, 2007. 
